\title{
Insurance Development and Economic Growth: An Examination of the Non-Bank Financial Institutions in Nigeria
}

\author{
David Okelue Ugwunta ${ }^{1} \&$ Uche Boniface Ugwuanyi ${ }^{2}$ \\ ${ }^{1}$ Department of Insurance and Risk Management, Enugu State University of Science and Technology, Nigeria \\ ${ }^{2}$ Department of Accountancy, Enugu State University of Science and Technology, Nigeria \\ Correspondence: David Okelue Ugwunta, Ph.D., Department of Insurance and Risk Management, Enugu State \\ University of Science and Technology, Nigeria. E-mail: david.ugwunta@esut.edu.ng.
}

Received: June 16, 2018

Accepted: November 7, 2018

Online Published: February 12, 2019

doi:10.5430/ijfr.v10n2p16

URL: https://doi.org/10.5430/ijfr.v10n2p16

\begin{abstract}
This paper determined the effect of the development of non-bank financial institutions on Nigeria's economic growth. Time series data, spanning a period of forty-one years, from 1970-2010 obtained from the Central Bank of Nigeria statistical bulletin were tested for stationarity. To measure the relationship and the impact of the explanatory variables on economic growth, the paper adopted a generic regression equation. Results suggest that total trade; investments of the insurance sector in financial asset; and insurance premiums have a high, positive and direct relationship with economic growth. Overall, our findings revealed that the focal variables insurance sector investment in financial assets; and insurance sector premiums significantly contribute to the economic growth of Nigeria.
\end{abstract}

Keywords: economic growth, insurance, financial assets, premium

\section{Introduction}

Choosing between competing sectors of the economy, firms and investments projects is a key role of financial intermediaries. If financial intermediations are carried out under restrictive regulations, then this "choice" is affected by how the regulations influence the enticements of the intermediary. Even in derestricted financial markets, intermediaries hold a part in "choosing" between differing demands because the distribution of investments based on price is not continuously probable. Financial intermediation has been inferred to be an encouragement to economic growth to a great deal. Opinions advanced as to why financial intermediation plays a vital part in economic growth include:

- Financial intermediation economizes the costs associated with mobilizing savings (Boyd and Smith, 1992; Sirri and Tufano, 1995), and therefore increases capital accumulation.

- Financial intermediaries evaluate firms, managers and market conditions in order to reallocate capital to its best use (Boyd and Prescott, 1986; Greenwood and Jovanovic, 1990; and Allen, 1990).

- Financial intermediaries monitor firms and exert control to overcome agency problems (Townsend, 1979; Gale and Hellwig, 1985; and Boyd and Smith, 1994).

- Financial intermediation makes it possible to diversify investment risks, which enhances output and economic growth (Gurley and Shaw, 1955; Greenwood and Jovanovic, 1990; and Acemoglu and Zilibotti, 1997). Under this view, differences in the quantity and quality of services provided by financial institutions partly explain why countries grow at different rates (Goldsmith, 1969; and Shaw, 1973).

- Financial intermediaries can evaluate, finance, and monitor potential entrepreneurs in their innovative activities. In integrating financial development into an innovation-based growth models, King and Levine (1993) suggest the relationship between finance and growth is likely to be dynamic and endogenous.

Burdened with part of shield establishment, insurance companies could affect economic growth through the channels of marginal productivity of capital and savings rate. Through indemnity, insurance companies underwrite the ones who suffer a loss and steady the financial situation of individuals and firms with likelihood of transfer of different kinds of risks to insurance companies. Given this, risk hostile economic units are more tempted to buy goods and 
services, especially those of higher value. In this way, insurance endures demands or consumptions for goods and services which boost production and employment. This result in a multiplier effects on the economy. Without devices for pooling and transfer of risk which insurance companies provide, a considerable part of the economic happenings would not take place and such positive effects on over-all economic wellbeing would not have been attained. In other words, by fashioning an environment of superior security, insurance nurtures investment and invention or economic growth.

The function of providing insurance coverage could affect economic growth through saving rate channel in a mixed way. On one side, insurance shield contributes to greater security which makes individuals and firms less cautious. Consequently, they could lower their safety savings. On the other side, by offering various life insurance products that combine risk shield and saving aids, insurance companies inspire long-term savings.

The importance of the insurance industry in the development process of a country has been acknowledged since 1964: a comprehensive insurance sector represents a crucial feature of a proper economic system, contributing to economic advance and nurturing high employment (UNCTAD, 1964). A truncated and irregular development of insurance, especially in the non-life lines of business, upsurges the level of risk in the economic choices taken by individuals and firms, impeding, in turn, economic activity. If insurance did not occur, a large proportion of the rest of the economy would not exist either. Without a dependable mechanism for mutualzation, assembling and relocating risk, a large portion of the economic activity would simply not take place.

The insurance market, both as financial intermediary and as benefactor of risk transfer and indemnification, may inspire economic growth by allowing dissimilar risks to be managed more efficiently, encouraging the buildup of new capital, and by assembling domestic savings into fruitful investments (Marco, 2006). The insurance activity, both as a provider of risk transfer and indemnification and as an institutional investor, may contribute to economic growth in the following ways (i) encouraging financial firmness, (ii) enabling trade and commerce (the most ancient insurance activity), (iii) activating domestic savings, (iv) permitting dissimilar risks to be managed more competently inspiring the accumulation of new capital, (v) nurturing a added effectual apportionment of domestic capital, and (vi) helping to reduce or mitigate losses (Marco 2006; citing Skipper, 1997). In addition, there are likely to be diverse effects on economic growth from life and non-life insurance (property / liability) given that these two types of cover protect the households and corporations from unalike risks that affect the economic activity in different ways. Likewise, because life insurance facilitates long-term investments rather than short-term investments as it is the case of non-life insurance.

Nevertheless, the influence of insurance activity on economic growth has remained unstudied extensively as the role of the banking sector and the stock market on economic growth. In this framework, the chore of this paper is to weigh whether insurance market activity stimuluses economic growth. Even though it is recognized that insurance activity not only would stimulus economic growth as a provider of risk and indemnification but also as an institutional investor by mobilizing savings, this study weighed the consequence of insurance on economic growth only as a provider of risk and indemnification. The rest of the paper is arranged thus; section two reviews the literature while the methodological framework is the concerns of section three. The findings are discussed in section four and the paper is concluded in section five.

\section{Review of Related Literature}

\subsection{Concept, Development and Types of Insurance}

According to Adebisi (2006) insurance is a thorny economic and social benefit for the management of risks to life and property. Agbaje (2005) opines that insurance as the business of assembling funds to pay compensation to the insured or assured (i.e. the policy holder) on the incidence of a specified event in exchange for a periodic consideration known as premium. Dickson (1960) is of the view that insurance is premeditated to guard the financial welfare of an individual, company or other entity in case of unpredicted loss. Gollier (2003) argue that insurance encompass the transmission of risk from an individual to a group, allotting losses on an impartial basis by all members of the group. Vaughan (1997) expresses insurance as a plan with a company in which regular amounts of premium is paid in agreement to pay the costs. Aweh (2008) opines that insurance eliminates risk of loss for the insureds by the mixture of a contribution of many people in the same position to a common fund, out of which an ill-fated may be indemnified of losses. Thus, insurance apparatus is an indispensable process to handle and control risk in a balanced and erudite manner. An effectual insurance industry offers vital and exceptional reimbursements for households, enterprises, commerce, government, and the financial sector. Private households profit through personal lines of insurance such as life, health or property insurance. Insurances enumerate the penalties of 
risk-taking by setting insurance premiums given an individual's risk (risk pricing). This allows insureds to pact reasonably with risks and averts them from perversely taking risky actions/decisions.

Insurance help the economic agents to avoid and condense losses. Insurance encourages and soothes entrepreneurship, production and commerce (CEA, 2006). Accordingly, insurance allows industry managers to meet the risk of impairment to production amenities, which increases their preparedness to invest. Besides, insurance develops the trustworthiness of economic agents. Trade and commerce are enabled when transportation, payment and goods are insured. Consumers on the other hand are invigorated to purchase large-expense items, such as automobiles or real estate. Insurance consequently serves as a "lubricant of commerce" nurturing consumption, entrepreneurship and innovation. Likewise, property/liability insurers can lessen costly disruption or even the entire bankruptcy of firms in case of unanticipated losses. They can minimize follow-up costs of financial distress. This helps to circumvent considerable capital waste and soothes business and the economy (CEA, 2006).

Insurances help to condense government spending meaningfully. Insurers can in part substitute for government security programs and discharge pressure on social welfare systems, conserving government resources for indispensable social security resolves. Besides, insurance of machines and production facilities is a qualification for their acceptance as collateral for bank credits (Marco, 2006). Moreover, insurance can headrest negative economic effects of natural catastrophes (such as crop loss) reducing the need for financial interventions by the state. Insurance markets play a crucial role for the development and efficient working of the financial sector.

Insurance companies are financial intermediaries (Islam and Osman, 2011). They decrease transaction costs from savers to borrowers by amassing large sums from thousands of small premium payers. Life insurers help to assemble and channel momentous savings to investments in corporate and government bonds, commercial mortgages and equity. Worldwide, life insurers have turn out to be a key source of long-term finance, which is chiefly important for evolving economies in necessity of investment for infrastructure projects. Growing obtainability of funds could be a consequence of insurance products by which insurance companies provide safety from credit risk to other financial intermediaries (Islam and Osman, 2011). Such that financial intermediaries are additionally keen to lend funds for financing real investments that encourage economic growth.

The function of providing insurance coverage could affect economic growth through saving rate channel in a mixed way. On the one side, insurance safety contributes to bigger security what makes individuals and firms less careful. Consequently, they could lower their precautionary savings. On the other side, by presenting various life insurance products that associate risk protection and saving benefits, insurance companies encourage long-term savings. Besides providing insurance, insurance companies could affect economic growth by function of resource accumulation and their allocation with managing various financial risks (Curak, Loncar and Poposki, 2009).

Agbakoba (2010) positions that insurance practice dates to the time when Lloyd's sent runners to the water front to pick up news of ship movements and later would send policy around London for subscription by anyone with sufficient means. Badejo (1998) argue that the concept of insurance in its modern form was introduced into Nigeria by the British in the closing years of the $19^{\text {th }}$ century with the establishment of trading posts by European trading companies mostly British. This is what is now known as Nigeria agents towards the end of the 19th century. These companies started effecting their insurance with established insurers in the London insurance market. As time went on, some British insurers appointed Nigerian agents to characterize their interest in the country. These agents later metamorphosed into full branch offices of their parent companies in Britain. Hausell (1990) submits that historically, only one insurance company operated in the country between 1914 and 1948. This was the overseas branch office of the Royal Exchange Assurance companies operating from its head office in the United Kingdom. Osunkunle (2002) opine that the first branch office in Nigeria of the Royal Exchange Assurance was in 1921, and later followed by other British companies. The first indigenous company to be established in Nigeria was African Insurance in 1950, this was to be trailed by the Nigerian General Insurance company in 1950 and the Lion of Africa insurance company in 1952 (Hausell, 1990). Indigenous Nigerian insurers and re-insurers later followed such as National Insurance Corporation of Nigeria (NICON) established in 1969 and Nigeria reinsurance companies operating in Nigeria today. Eke (1992) posited that as at 31st December 1996, there were 135 insurance companies functioning in the Nigerian insurance market with comparative figures of 145 (1995) and 130 (1993). Most of these companies are privately owned indigenous shareholders (118 companies as at 31st December, 1995). Lynch (1992) posits that insurance companies have constantly been on the increase since early sixties. This has been due to liberal financial legal requirements. Insurance assemble long-term funds and act as financial intermediaries. Their investment activities are mainly in government securities, public sector enterprises and the mortgage industry. The Nigeria reinsurance corporation was established in 1977 to provide insurance cover for insurance companies (Adaramola, 2002). 
Insurance business is usually divided into two main classes namely: General or non-life insurance business and Life assurance business (Adaramola, 2002). General or non-Life Business - This is a contract between an insurer (i.e. the insurance company) and the insured where by the insurer assumes to indemnify the assured against losses, which may result from the incidence of specified events within specified periods. General insurance business can be sub-divided into: fire, accident, oil and gas, contractors' all risks and engineering risks; marine and Credit insurance, bond and surety ship etc. Life assurance is a contract between the assurer (the company) and the assured (i.e. the policy holder) whereby the assurer undertakes to pay reimbursements to the policy holder on the attainment of a specified event. This type of insurance is long term in nature. Life Assurance business comprises individual life business, group life insurance and pension business, health insurance business and annuities.

\subsection{Insurance and Economic Growth}

Providing protection, insurers could affect economic growth through the channels of marginal productivity of capital, technological revolutions and saving rate (CEA, 2006). Insurance companies indemnify the ones who suffer a loss and stabilize the financial position of individuals and firms. With possibility of transmission of different kinds of risks to insurance companies, risk hostile economic units are encouraged to buy goods and services, especially those of higher values. In this way insurance endures consumption for goods and services which boost production, employment and finally, economic growth. Firms exposed to various risks of their liability, property, illness and disability of their employees, and life of key employees, have likelihood of handling those risks by transfer to insurance companies. This allows firms to concentrate resources on core businesses. Therefore, firms willingly and ably take real investments that consequence in higher rate of economic growth. Additionally, entrepreneurs are fortified to encompasse not just present products and production processes, but to also include technological innovation. Notably, being innovative supposes the readiness to take the risk. Although insurance cannot change the risk attitude of economic units (risk aversion does not change with insurance) it plays a key role in freeing entrepreneurial spirit (CEA, 2006). Therefore, insurance aids entrepreneurs to take innovative and higher-return projects. Without mechanism for mutualisation, pooling and transferring risk which insurance companies provide, part of this economic activities would not take place and such encouraging effects on social welfare would fail. In other words, by creating an environment of greater security, insurance nurtures investment and innovation or economic growth.

\subsection{Empirical Review}

Contrasting to the vast empirical studies on the relationship between banking intermediation and economic growth, very few empirical lessons have examined the role of insurance on economic growth. Most of the studies on non-bank financial institutions, however, have fixated on either pension funds or contractual savings (assets of pension funds and life insurance companies) with respect to their impact on national savings or other financial development such as the stock market development. Scholars have also looked at insurance markets in different countries and over different time periods, applying varying econometric techniques to distinct and control for the effects of many known factors in growth, as well as to identify the probable causal direction between these factors and growth. These studies have sought not only to understand whether insurance makes an important contribution, but also if this contribution can be measured empirically.

Table 1. Summary of empirical review

\begin{tabular}{|c|c|c|c|}
\hline Author(s) & Objective & Method of Analysis & Findings \\
\hline $\begin{array}{l}\text { Murphy and } \\
\text { Musalem (2004) }\end{array}$ & $\begin{array}{l}\text { effect of the } \\
\text { accumulation of } \\
\text { pension funds } \\
\text { financial assets on } \\
\text { national savings }\end{array}$ & $\begin{array}{l}\text { Ordinary Least Squares } \\
\text { (OLS) and 2OLS estimation } \\
\text { on a panel of } 43 \text { countries } \\
\text { including several developed } \\
\text { and developing countries } \\
\text { over the period 1960-2002. }\end{array}$ & $\begin{array}{l}\text { failed to show a direct link between the } \\
\text { accumulation of pension funds' assets } \\
\text { and the economic growth }\end{array}$ \\
\hline $\begin{array}{l}\text { Granville and } \\
\text { Mallick (2004) }\end{array}$ & $\begin{array}{l}\text { accumulation of } \\
\text { pension funds, } \\
\text { financial assets on } \\
\text { national savings }\end{array}$ & $\begin{array}{l}\text { Ordinary Least Squares } \\
(\mathrm{OLS}) \text { and 2-stage OLS } \\
\text { estimation }\end{array}$ & $\begin{array}{l}\text { found positive and significant } \\
\text { correlation between total national } \\
\text { savings and the pension savings in the } \\
\text { case of the UK. }\end{array}$ \\
\hline
\end{tabular}




\begin{tabular}{|c|c|c|c|}
\hline $\begin{array}{l}\text { Islam and } \\
\text { Osman (2011) }\end{array}$ & $\begin{array}{l}\text { existence of a long } \\
\text { run equilibrium } \\
\text { relationship between } \\
\text { NBFIs and } \\
\text { economic growth }\end{array}$ & $\begin{array}{l}\text { bounds testing approach to } \\
\text { cointegration and error } \\
\text { correction mechanism }\end{array}$ & $\begin{array}{l}\text { suggestion of a long run cointegrating } \\
\text { relationship between NBFIs and real } \\
\text { per capita income. The empirical } \\
\text { results indicate that the development of } \\
\text { NBFIs positively and significantly } \\
\text { influences per capita income in } \\
\text { Malaysia. }\end{array}$ \\
\hline $\begin{array}{l}\text { Haiss and } \\
\text { Sümegi (2006) }\end{array}$ & $\begin{array}{lr}\text { reviewing } & \text { theory } \\
\text { and } & \text { empirical } \\
\text { evidence } & \end{array}$ & $\begin{array}{l}\text { cross-country panel data } \\
\text { analysis using annual } \\
\text { insurance premium data } \\
\text { from } 29 \text { European countries } \\
\text { over the } 1992 \text { to } 2004 \\
\text { period }\end{array}$ & $\begin{array}{l}\text { weak evidence for a growth supporting } \\
\text { role of life insurance }\end{array}$ \\
\hline $\begin{array}{l}\text { Cheng and } \\
\text { Degryse (2007) }\end{array}$ & $\begin{array}{l}\text { impact of banks and } \\
\text { non-bank financial } \\
\text { institutions on local } \\
\text { economic growth }\end{array}$ & $\begin{array}{l}\text { Employed OLS to data for } \\
27 \text { Chinese provinces over } \\
\text { the period 1995-2003 }\end{array}$ & $\begin{array}{l}\text { banks have had a greater impact than } \\
\text { non-banks on local economic growth as } \\
\text { they profited earlier and more } \\
\text { profoundly from China's financial } \\
\text { reforms than their non-bank } \\
\text { counterparts }\end{array}$ \\
\hline Marco (2006) & $\begin{array}{l}\text { tested whether there } \\
\text { is a causal } \\
\text { relationship between } \\
\text { insurance market } \\
\text { activity (life and } \\
\text { non-life insurance) } \\
\text { and economic } \\
\text { growth }\end{array}$ & $\begin{array}{l}\text { generalized method of } \\
\text { moments for dynamic } \\
\text { models of panel data for } 56 \\
\text { countries and for the } \\
1976-2004 \text { period }\end{array}$ & $\begin{array}{l}\text { vigorous indication of a causal } \\
\text { relationship between insurance market } \\
\text { activity and economic growth. Both life } \\
\text { and non-life insurance have a positive } \\
\text { and significant causal effect on } \\
\text { economic growth }\end{array}$ \\
\hline $\begin{array}{l}\text { Haiss } \quad \text { and } \\
\text { Sümegi, (2009) }\end{array}$ & $\begin{array}{l}\text { investigated both the } \\
\text { impact of insurance } \\
\text { investment and of } \\
\text { premiums on GDP } \\
\text { growth in Europe }\end{array}$ & $\begin{array}{l}\text { cross-country panel data } \\
\text { analysis over } 1992 \text { to } 2005 \\
\text { for } 29 \text { European countries }\end{array}$ & $\begin{array}{l}\text { positive impact of life insurance on } \\
\text { GDP growth in the mature EU-15 } \\
\text { countries, Switzerland, Norway and } \\
\text { Iceland. For the New EU Member } \\
\text { States from Central and Eastern } \\
\text { Europe, we find a larger impact for } \\
\text { liability insurance }\end{array}$ \\
\hline $\begin{array}{l}\text { Mojekwu, } \\
\text { Agwuegbo and } \\
\text { Olowokudejo } \\
\text { (2011) }\end{array}$ & $\begin{array}{l}\text { impact of insurance } \\
\text { contributions on } \\
\text { economic growth in } \\
\text { Nigeria }\end{array}$ & $\begin{array}{l}\text { twenty-seven-year period, } \\
\text { between } 1981 \text { and } 2008 \\
\text { using a dynamic factor } \\
\text { model }\end{array}$ & $\begin{array}{l}\text { functional relationship between the } \\
\text { volume of insurance contribution and } \\
\text { economic growth in Nigeria is a first } \\
\text { order vector autoregressive model }\end{array}$ \\
\hline Omoke (2012) & $\begin{array}{l}\text { determining its } \\
\text { impact on economic } \\
\text { growth }\end{array}$ & $\begin{array}{l}\text { Johansen cointegration and } \\
\text { vector error correction } \\
\text { approach }\end{array}$ & $\begin{array}{l}\text { insurance sector did not reveal any } \\
\text { positively and significant effect on } \\
\text { economic growth in Nigeria within the } \\
\text { period of study }\end{array}$ \\
\hline $\begin{array}{l}\text { Han, } \quad \text { Li, } \\
\text { Moshirian and } \\
\text { Tian (2010) }\end{array}$ & $\begin{array}{l}\text { investigated the } \\
\text { relationship between } \\
\text { insurance } \\
\text { development and } \\
\text { economic growth }\end{array}$ & $\begin{array}{l}\text { GMM models on a dynamic } \\
\text { panel data set of } 77 \\
\text { economies for the period } \\
1994-2005\end{array}$ & $\begin{array}{l}\text { insurance development is positively } \\
\text { correlated with economic growth }\end{array}$ \\
\hline $\begin{array}{l}\text { Ege and Sarac } \\
\text { (2011) }\end{array}$ & $\begin{array}{l}\text { role of insurance in } \\
\text { economic growth }\end{array}$ & $\begin{array}{l}\text { Twenty-nine countries' data } \\
\text { in } 1999 \text { and } 2008 \text { were } \\
\text { applied with regression } \\
\text { analysis }\end{array}$ & $\begin{array}{l}\text { insurance sector and the economic } \\
\text { growth are positively related }\end{array}$ \\
\hline
\end{tabular}




\begin{tabular}{|c|c|c|}
\hline $\begin{array}{ll}\text { Ćurak, } & \text { Lončar } \\
\text { and } & \text { Poposki } \\
(\mathbf{2 0 0 9}) & \end{array}$ & $\begin{array}{l}\text { examined } \\
\text { relationship between } \\
\text { insurance sector } \\
\text { development and } \\
\text { economic growth }\end{array}$ & $\begin{array}{l}10 \text { transition European } \\
\text { Union member countries, in } \\
\text { the period from } 1992 \text { to } \\
2007 \text { were applied with } \\
\text { fixed-effects panel model }\end{array}$ \\
\hline $\begin{array}{l}\text { Owojori and } \\
\text { Oluwagbuyi } \\
\text { (2011) }\end{array}$ & $\begin{array}{l}\text { investigated } \\
\text { contribution } \\
\text { insurance } \\
\text { economic } \\
\text { development } \\
\text { Nigeria }\end{array}$ & $\begin{array}{l}\text { a descriptive survey, with a } \\
\text { sample of } 10 \text { companies of } \\
4 \text { life and } 6 \text { non-life } \\
\text { insurance using random } \\
\text { sampling techniques }\end{array}$ \\
\hline
\end{tabular}

insurance sector development positively and significantly affects economic growth

problem among insurance companies were lack of funds which leads to claim avoidance. There was no significant difference between performance of insurance policy in urban and rural areas. Insurance companies provide financial services to some substantial number of people in the economy. The findings further revealed that insurance helps in capital accumulation than payment of reparation of loses.

\begin{tabular}{lll}
\hline Arena (2006) & tested whether there & generalized method of \\
& is a causal & moments for dynamic \\
& relationship between & models of panel data for 56 \\
insurance market & countries and for the \\
& activity (life and & $1976-2004$ period \\
& non-life insurance) \\
and & economic \\
growth &
\end{tabular}

robust evidence of a causal relationship between insurance market activity and economic growth. Both life and non-life insurance have a positive and significant causal effect on economic growth. High-income countries drive the results in the case of life insurance. On the other hand, both high-income

\section{examined the short fixed-effect model was} and long-run relationships between insurance sector development and economic growth in Nigeria applied to dataset of 1985 to 2009 aided by co-integration analysis and Granger causality and developing countries drive the results in the case of non-life insurance.

insurance sector growth and

development positively and significantly affects economic growth. Granger causality test also revealed that the extent of influence the insurance sector growth had on economic growth was limited and not direct because of some cultural, attitudinal traits and values in the country

\begin{tabular}{|c|c|c|c|}
\hline $\begin{array}{lr}\text { Gupta, } & \text { Yesmin } \\
\text { and } & \text { Khan } \\
(\mathbf{2 0 1 3}) & \end{array}$ & $\begin{array}{l}\text { addressed the } \\
\text { growth of insurance } \\
\text { industry and its } \\
\text { change over time }\end{array}$ & $\begin{array}{l}\text { adopting growth measures } \\
\text { based on asset, loan, income } \\
\text { and expenditure using time } \\
\text { series analysis and } \\
\text { correlation coefficient }\end{array}$ & $\begin{array}{l}\text { a growth of NBFIs over the years in } \\
\text { advances, income, assets and others } \\
\text { financial aspect and a good } \\
\text { contribution in the GDP growth of } \\
\text { Bangladesh. }\end{array}$ \\
\hline $\begin{array}{l}\text { Rateiwa } \\
\text { Aziakpono } \\
\text { (2017) }\end{array}$ & $\begin{array}{l}\text { existence of a } \\
\text { long-run equilibrium } \\
\text { relationship between } \\
\text { economic growth } \\
\text { and the development } \\
\text { of NBFIs }\end{array}$ & $\begin{array}{l}\text { the causality thereof using } \\
\text { time-series data from } \\
\text { Africa's three largest } \\
\text { economies, namely, Egypt, } \\
\text { Nigeria and South Africa, } \\
\text { over the period 1971-2013. } \\
\text { Using the Johansen } \\
\text { cointegration and vector } \\
\text { error correction model } \\
\text { within a country-specific } \\
\text { setting }\end{array}$ & $\begin{array}{l}\text { long-run relationship between NBFI } \\
\text { development and economic growth is } \\
\text { relatively stronger in Egypt and South } \\
\text { Africa, than in Nigeria. The nature of } \\
\text { the relationship between NBFI } \\
\text { development and economic growth in } \\
\text { Egypt is positive and significant, and } \\
\text { predominantly bidirectional. In Nigeria, } \\
\text { the results are weak and mixed }\end{array}$ \\
\hline
\end{tabular}

Source: Author's Compilation, 2018. 
Certain studies examined the development impact of NBFIs in terms of leasing and factoring companies, insurance companies, pension funds or mutual funds on capital market development and economic activities (e.g., Impavido and Musalem, 2000; Catalan, Impavido and Musalem, 2000; Impavido et al., 2003; Vitas, 1997, 2003; Fernando, Klapper, Sulla and Vittas, 2003 and so on). These studies in general conclude that better developed NBFIs (in their various forms such as contractual savings, mutual funds, leasing and factoring) play important role as an engine that accelerates growth by complementing the services provided by banking institutions and by providing a strong stimulant to the development of capital market. Also, two separate country specific studies found that there is no long-run relationship between economic growth and NBFIs when using assets and liabilities of finance and discount houses as indicators of NBFIs (Osuala and Odunze, 2014 and Ndugbu, 2015).

NBFIs compliment roles as an alternative source of funds through amassing vast long-term financial resources and conducting them to economy through capital market. Thus, from the review of the finance-growth literature, financial sector development in terms of both banking institutions and non-bank financial institutions (NBFIs) play key roles in expanding of economic development. However, this study attempted to bring into discussion the importance of NBFIs in finance-growth literature by specifically investigating the relationship between economic growth and NBFIs in Nigeria. This is the gap this paper intends to fill in the finance-growth literature.

\section{Methodological Framework}

In this study, annual data, spanning a period of forty-one years, from 1970-2010 (based on available data as at 2016) were used. Data were obtained from the Central Bank of Nigeria statistical bulletin. To measure the relationship between GDP and other explanatory variables we adopt the generic regression equation as applied by Islam and Osman (2011) and Marco (2006) specified in the following form:

$$
Y_{\mathrm{t}}=f\left(F A_{t}, I N_{t}, T D_{t}\right)+\mathrm{u}_{\mathrm{t}}
$$

Where $Y \mathrm{t}=$ GDP.

$\mathrm{FA}_{\mathrm{t}}=$ Total Financial Assets of NBFIs (insurance) to GDP.

$\mathrm{TT}_{\mathrm{t}}=$ Total Trade to GDP.

$\mathrm{PM}_{\mathrm{t}}=$ Insurance Premium to GDP.

Expressing the relation in linear form using the growth rates of the variables, we arrive at the following estimating equation:

$$
\mathrm{GRY}_{\mathrm{t}}=\mathrm{X}_{0}+\mathrm{X}_{1} \mathrm{GRFA}_{\mathrm{t}}+\mathrm{X}_{2} \mathrm{GRTT}_{\mathrm{t}}+\mathrm{X}_{3} \mathrm{GRPM}_{\mathrm{t}}+\mathrm{U}_{\mathrm{t}}
$$

The $Y_{t}$, Premium and $F_{t}$ are the focal variables in the analysis measuring economic growth and indicator of NBFIs development respectively.

\subsection{Description of Variables}

\subsubsection{Dependent Variable}

Gross Domestic Product is the value of goods and services produced in Nigeria during the period of the study. GDP at current basic prices is simply nominal GDP equals GDP less indirect taxes net of subsidies (CBN Statistical bulletin, 2007). The growth rate in Gross Domestic Product, a broadly approved degree of economic growth was used as a proxy for Nigerian economic growth.

\subsubsection{Independent Variables}

FA (Financial Asset). Investment in Financial Asset is adopted as a measure of NBFIs development indicator (Islam and Osman, 2011). This independent variable is proxied as the growth rate of investment of the Insurance sector for this study. Financial assets for the insurance industry include a total investment in government securities as well as stocks \& bonds. This measures magnitude of the sector relative to the economy. Indicating a larger NBFIs expansion and hence greater intermediation activities and/ or vice versa. Insurance sector's investment in financial asset is expected to be positively related and impacts on Nigeria's GDP.

$T D_{t}$ is the total trade (exports + imports). The insurance sector theatres the protection to an economy's imports as well as exports thereby encouraging international trade. This variable captures an economy's trade openness as a proportion of GDP used as total trade in relation to GDP while expecting that exports are positively related with economic growth.

Insurance premiums measures of penetration of insurance activity in the economy in relation to a country's GDP. Marco (2006) notes this explanatory variable as a variable of interest as it measures a country's insurance market 
development and proxied by the ratio of life insurance premiums to GDP and the ratio of non-life (property-liability) insurance premiums to GDP. The use of premiums as a proxy for insurance market activity would only capture the role of life and non-life insurance companies as providers of risk transfer and indemnification not their role as institutional investors.

The subscript $t$ represents the time. Where Logn indicates natural $\log$, are the parameters to be estimated ${ }_{\text {and }} \mathrm{u}_{\mathrm{t}}$ is an error term. The variables are transformed into logarithmic form to minimize the scale effect of numbers.

\subsubsection{Data Testing Procedure}

Stationary properties of the time series data before the first stage of the model were estimated. Therefore, stationary statuses of the variables were investigated by the Augmented Dickey Fuller (ADF) unit root test to guard against spurious regression results.

The expected signs of all the coefficients are positive. The data are time series with an annual observation and covers the period 1970-2010 (based on available data in CBN Statistical Bulletin 2016). The bounds testing procedure is the Ordinary Least Square (OLS). The test is done in two stages. First, we test for data stationary. Secondly, we test for relationships and magnitude.

\section{Findings and Result}

A review of the data over the last forty years reveals that insurance consumption is not only strongly correlated with economic output; its growth outpaces that of the economy as shown in the figure below.

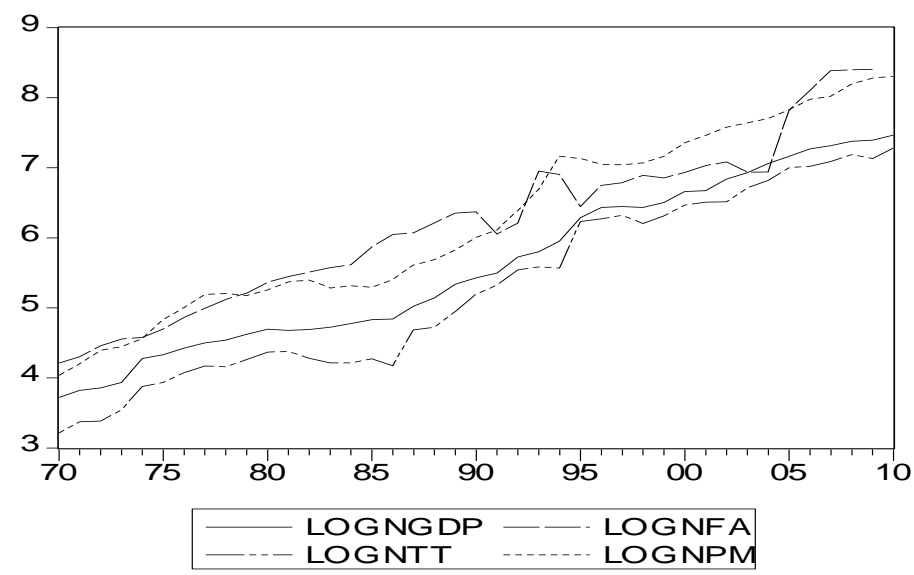

Figure 1. Graphical representation of the data relationship

Source: Author's Eview output.

In Figure1, the logn premium is above the GDP. USAID (2006) pointed out that the growth of insurance consumption (measured as insurance penetration or total premiums as a relation of GDP) generally follows what is referred to as an "S-Curve": it is slower at lower levels of development, accelerates as the insurance market and the economy expand, and then slows down again as the market matures. Therefore, Fig. 1 shows that the Nigerian insurance market has gone through the development and expansion stages but is yet to mature to complete the "S-Curve". Investment in financial asset also lies above GDP on Fig. 1 but intercepts GDP in year 2005. Total trade is however lying below the GDP line suggesting that GDP outgrows total trade. This indicates that the country's international trade especially export is not performing optimally and perhaps not contributing optimally to GDP.

The stationarity properties were examined, and the outcome presented in Table 2.

\subsection{Unit Root Test Result}

A time series is stationary if its mean and variance are independent of time. 
Table 2. Augmented dickey fuller

\begin{tabular}{lll}
\hline Variables & ADF Test Statistic (t*) & Critical value* \\
\hline Logn GDP & -6.423579 & -3.6171 \\
\hline Logn Financial Asset & -6.423579 & -3.6171 \\
\hline Logn Premium & -3.858676 & -3.6117 \\
\hline Logn Total Trade & -4.353493 & -3.6117 \\
\hline
\end{tabular}

Source: Author's Eview output.

A non-stationary time series can be converted into a stationary time series by differencing. The augmented dickey fuller (ADF) stationary test for the time series as presented in Table 1 above are found to be significant at $1^{\text {st }}$ difference. Observing the critical values and the observed $t^{*}$, we conclude that there is no unit root with the time series. Therefore, the time series are stationary.

\subsection{Relationship}

The relationship between the dependent and the independent variables, their strength and weakness are revealed by the pairwise correlation shown in Table 3.

Table 3. Pairwise correlation

\begin{tabular}{lllll}
\hline VARIABLES & LOGNGDP & LOGNTT & LOGNFA & LOGNPM \\
LOGNGDP & 1 & & & \\
LOGNTT & 0.996982 & 1 & & \\
LOGNFA & 0.959099 & 0.946334 & 1 & 1 \\
LOGNPM & 0.994638 & 0.992139 & 0.961259 & 1 \\
\hline
\end{tabular}

Source: Author's Eview output.

The signs are positive with respect to GDP indicating a positive relationship. The positivity is very strong $(0.99,0.95$ \& 0.99 , which are $99 \%, 95 \%$ \& $99 \%$ for total trade, investment in fixed asset, and premiums respectively) suggesting that an increase in total trade, investment in fixed asset, and premiums brings about an increase in GDP.

To the positive relationships of the pairwise correlations, the unbiased result of the regression analysis shows that the results are statistically significant suggesting an impact on economic growth as shown in Table 4.

Table 4. Regression result

\begin{tabular}{|c|c|c|c|c|}
\hline \multicolumn{5}{|c|}{ Dependent Variable: LOGNGDP } \\
\hline Variable & Coefficient & Std. Error & $\mathrm{t}$-Statistic & Prob. \\
\hline LOGNTT & 0.643738 & 0.071700 & 8.978151 & 0.0000 \\
\hline LOGNFA & 0.106516 & 0.035130 & 3.032071 & 0.0045 \\
\hline LOGNPM & 0.181118 & 0.083726 & 2.163230 & 0.0372 \\
\hline $\mathrm{C}$ & 0.403265 & 0.083301 & 4.841047 & 0.0000 \\
\hline R-squared & 0.996735 & \multicolumn{2}{|c|}{ Mean dependent var } & 5.548893 \\
\hline Adjusted R-squared & 0.996462 & \multicolumn{2}{|c|}{ S.D. dependent var } & 1.154871 \\
\hline S.E. of regression & 0.068689 & \multicolumn{2}{|c|}{ Akaike info criterion } & -2.423818 \\
\hline Sum squared resid & 0.169854 & \multicolumn{2}{|c|}{ Schwarz criterion } & -2.254930 \\
\hline Log likelihood & 52.47636 & \multicolumn{2}{|c|}{ F-statistic } & 3662.824 \\
\hline Durbin-Watson stat & 1.966491 & \multicolumn{2}{|c|}{ Prob(F-statistic) } & 0.000000 \\
\hline
\end{tabular}

Source: Author's Eview output, 2018.

The study discovered from the multiple linear regressions that total trade, investment in financial asset and premiums had statistically significant effect on the Nigerian economy as $\left(t_{c}=8.978151,3.032071,2.163230\right.$ for total trade, investment in fixed asset, premiums respectively $>t^{*}=2.000$ ). These results are further strengthened with the 
(p-value $=0.0000,0.0045,0.0372$ for total trade, investment in fixed asset, premiums respectively $<\mathrm{p}^{*}=0.05$. The +ve sign indicates a direct relationship between total trade, investment in financial asset and premium. This suggests that total trade, insurance sector investment in financial asset and insurance premiums contributes to the growth of the Nigerian economy. These results are in line with a priori expectations and with the findings of (Islam and Osman, 2011; Marco, 2012; Omoke, 2012; and Curak, Loncar and Poposki, 2009). The multiple regression models are thus written as: GDP $=0.403265+0.643738^{*} \operatorname{lognTT}+0.106516_{* \operatorname{lognFA}}+0.18111{ }^{*}{ }^{*} \operatorname{lognPM}$.

\section{Conclusion}

This paper sets out to determine if the Nigeria's insurance sector contributes to its economic growth. The empirical results show that total trade; investments of the insurance sector in financial asset; and insurance premiums have a high, positive and direct relationship with economic growth. Overall, the findings revealed that insurance sector investment in financial assets; and insurance sector premiums significantly impacts on Nigeria's Gross Domestic Product. Therefore, the national activity, the penetration and the development of the Nigeria's insurance sector contributes positively to the growth of the Nigerian economy. Thus, these findings add to existing review of the finance-growth literature and suggest that non-bank financial institutions (NBFIs) play key roles in expanding economic development. This study brought into discussion the importance of NBFIs in finance-growth literature in Nigeria. Thus, NBFIs compliment roles of long-term financial resources and conducting them to economy.

Notwithstanding the findings of this paper there exist areas of improvements for the Nigerian insurance sector to achieve stellar results. Micro insurance, a vital tool to eliminate poverty is almost non-existent in the Nigerian insurance sector. The Insurance firms in Nigeria can do better if they are able to develop micro insurance products that will be designed specifically for the poor, who are either farmer, self-employed or employed in the small and medium scale firms and do not have access to insurance products. Also, an optimal regulatory environment is needed to allow the insurance sector to activate fully its role in the economy. This implies less burdensome regulation, better adapted to the real needs of insurers and customers in Nigeria. The regulatory environment for insurance should encourage risk-based pricing.

\section{References}

Acemoglu, D., \& Zilibotti, F. (1997). Was prometheus unbound by chance? Risk, diversification and growth. Journal of Political Economy, 105, 709-775. https://doi.org/10.1086/262091

Adebisi, W. (2006). Principles and Practice of Insurance (1st ed.). Akure, Ondo: Adefemi Publisher.

Agbaje, A. R. (2005). Accounting for Specialized Transactions (1st ed.). Mokola, Ibadan: Akins Prints.

Agbakoba, O. (2010). The Case of Property-Liability Insurance. New York: Wiley Publishers.

Allen, F. (1990). The market for information and the origin of financial intermediaries. Journal of Financial Intermediation, 22(1), 3-30. https://doi.org/10.1016/1042-9573(90)90006-2

Badejo, M. (1998). Limitations and scope of insurance. Akure, Ondo: Hydrid Publishers Limited.

Boyd, J. H., \& Prescott, E. C. (1986). Financial intermediary-coalitions. Journal of Economic Theory, 38(1), 211-232. https://doi.org/10.1016/0022-0531(86)90115-8

Boyd, J. H., \& Smith, B. D. (1992). Intermediation and the equilibrium allocation of investment capital: implications for economic development. Journal of Monetary Economics, 30(1), 409-432. https://doi.org/10.1016/0304-3932(92)90004-L

Boyd, J. H., \& Smith, B. D. (1994). How good are standard debt contracts? Stochastic versus non-stochastic monitoring in a costly state verification environment. Journal of Business, 67(1), 539-562. https://doi.org/10.1086/296646

CEA (Comité Européen des Assurances). (2006). The Contribution of the Insurance Sector to Economic Growth and Employment in the EU. Retrieved June 22, 2012, from http://www.cea.assur.org

Ćurak, M., Lončar, S., \& Poposki, K. (2009). Insurance sector development and economic growth in transition countries. International Research Journal of Finance and Economics, 11(2), 29-41.

Devereux, M. B., \& Smith, G. W. (1994). International risk sharing and economic growth. International Economic Review, 35(4), 535-550. https://doi.org/10.2307/2527072

Dickson P. G. M. (1960). The Sun Insurance Office: The History of Two and a half centuries of British Insurance, Vol. 1, No. 40. London. 
Ege, I., \& Sarac, T. B. (2011). The relationship between insurance sector and economic growth: an econometric analysis. International Journal of Economic Research, 2(2), 1-9.

Eke, E. (1992). Principle of Insurance. Ibadan: Dekaal Publishers.

Gale, D., \& Hellwig, M. (1985). Incentive-compatible debt contracts: the one-period problem. Review of Economic Studies, 52(2), 647-663. https://doi.org/10.2307/2297737

Goldsmith, R. W. (1969). Financial structure and development. Yale University Press: New Haven, CT.

Gollier, C. (2003). To insure or not insure? an insurance puzzle. The Geneva Papers on Risk and Insurance theory. https://doi.org/10.1023/A:1022112430242

Greenwood, J., \& Jovanovic, B. (1990). Financial development, growth, and the distribution of income. Journal of Political Economy, 98(1), 1076-1107. https://doi.org/10.1086/261720

Gupta, A. D., Yesmin, A., \& Khan, M. O. F. (2013). Growth of non-bank financial institutions over time and contribution to economy: evidence from Bangladesh. Global Journal of Management and Business Research Finance, 13(6), 16-23.

Gurley, J. G., \& Shaw, E. S. (1955). Financial aspects of economic development. American Economic Review, 45(2), 515-538.

Islam. M., \& Oslam. J. (2011). Development impact of non-bank financial intermediaries on economic growth in Malaysia: An empirical investigation. International Journal of Business and Social Sciences, 2(14), 187-198.

Jappelli, T., \& Pagano, M. (1994). Saving, growth and liquidity constraints. Quarterly Journal of Economics, 109(1), 83-109. https://doi.org/10.2307/2118429

King, R. G., \& Levine, R. (1993). Finance, entrepreneurship and growth: theory and growth. Journal of Monetary Economics, 32(2), 513-542. https://doi.org/10.1016/0304-3932(93)90028-E

Liang, H., \& Reichert, A. (2015). The impact of banks and non-bank financial institutions on economic growth. The Service Industries Journal, 32(5), 699-717. https://doi.org/10.1080/02642069.2010.529437

Lynch, E. (1992). Health insurance terminology. Ado-Ekiti: Olugbenga press publishers.

Marco, A. (2006). Does insurance market activity promote economic growth? a cross-country study for industrialized and developing countries. World Bank Policy Research Working Paper 4098.

Ndugbu, M. (2015). Bank and non-bank financial institutions and the development of the Nigerian economy. International Journal for Innovation Education and Research, 3(8), 67-80.

Oke, M. O. (2012). Insurance sector development and economic growth in Nigeria. African Journal of Business Management, 6(23), 7016-7023. https://doi.org/10.5897/AJBM11.2853

Osuala, A., \& Odunze, C. (2014). Do non-bank financial institutions' loans and advances influence economic growth? a bounds test investigation. European Journal of Business and Management, 6(4), 27-40.

Osunkunle, B. (2002). Impact of Insurance in Nigeria. Ibadan: Evans Brothers Publishers.

Owojori, A. A., \& Oluwagbuyi, L. O. (2011). The effect of insurance business on economic development in Nigeria. Journal of Emerging Trends in Economics and Management Sciences, 2(4), 275-280.

Rateiwa, R., \& Aziakpono, M. J. (2017). Non-bank financial institutions and economic growth: Evidence from Africa's three largest economies. South African Journal of Economic and Management Sciences, 20(1), 15-45.

Shaw, E.S. (1973). Financial deepening in economic development. New York: Oxford University Press.

Sirri, E. R., \& Tufano, P. (1995). The economics of pooling, the global financial system: a functional perspective, pp. 81-128. Boston, MA: Harvard Business School Press.

Townsend, R. M. (1979). Optimal contracts and competitive markets with costly state verification. Journal of Economic Theory, 21, 265-293. https://doi.org/10.1016/0022-0531(79)90031-0

USAID. (2006). Assessment on how Strengthening the Insurance Industry in Developing Countries Contributes to Economic Growth. Final Report.

Vaughan, E. J. (1997). Risk management. New York: Wiley publishers. 